\title{
Combining Patronage and Merit in Public Sector Recruitment
}

\author{
Sarah Brierley*
}

March 17, 2019

*Assistant Professor, Department of Political Science, Washington University in St. Louis. Email: sabrierley@wustl. edu. 


\begin{abstract}
When do politicians in developing democracies prioritize meritocratic recruitment over patronage hiring for public sector jobs? I distinguish between menial and professional positions and argue that the former are valuable for sustaining party machines, while manipulating the latter can undermine state performance. Accordingly, politicians will interfere to ensure their co-partisans are hired to menial positions but select professional bureaucrats based on meritocratic criteria. I test my argument using novel bureaucrat-level data from Ghana $(n=17,942)$ and leverage a change in the governing party to investigate hiring patterns. The results suggest that partisan bias is confined to menial jobs. The findings shed light on the mixed effects of electoral competition on patronage identified in prior studies: competition may dissuade politicians from interfering in recruitment to high-ranked positions, but encourage them to hire partisans for low-ranked positions.
\end{abstract}

Key words: Bureaucracy; Civil Service, Patronage; Meritocracy; Clientelism; Brokers.

Supplementary material for this article is available in the appendix in the online edition. Replication files are available in the JOP Data Archive on Dataverse http: //thedata.harvard.edu/dvn/dv/jop. 
Whether civil servants are hired based on merit or political criteria has broad implications for state capacity and the overall health of democracy (O’Dwyer, 2006; Grzymala-Busse, 2007; Geddes, 1994). Patronage recruits are likely to be less competent and also not essential to the running of the state. This type of hiring can place an unnecessary strain on the public purse, and undermine investment in other vital areas, such as capital infrastructure. It can also perpetuate a broader clientelistic political economy. Once hired, co-partisan bureaucrats can help politicians allocate scarce public resources in sub-optimal ways. ${ }^{1}$ Partisan appointees may also worsen the provision of public services (Colonnelli, Prem and Teso, 2017) and increase levels of corruption (Oliveros and Schuster, 2018).

Given these high stakes, it is important to understand when politicians in developing democracies are more likely to rely on meritocratic versus partisan recruitment. Prior research has not been able to adequately address this question because, by using changes in legislation to signal the onset of meritocracy (Geddes, 1994), it treats the concept of meritocracy as dichotomous. Other research similarly assumes the question away by portraying post-colonial states as neopatrimonial, a situation in which all public sector jobs are often assumed to be distributed politically (Bayart, 1993; Chabal and Daloz, 1999; Van de Walle, 2001).

Despite this dominant narrative, in practice most countries lie on a continuum between complete meritocracy and wholesale partisan interference (Grindle, 2012). I build on this insight and consider when the benefits of patronage hiring are outweighed by the costs. I theorize that the costs of non-competitive recruitment vary across public sector positions, and therefore that politicians may support meritocratic recruitment for some posts and actively interfere in hiring for others. Meddling in hiring for professional positions, such as budget analysts, engineers, and planning officers, is costly to politicians. It can hurt incumbents electorally because it can impact state performance. In contrast, interference in low-ranking public sector jobs, such as sanitation officers, laborers, and security guards, poses a lower risk to state performance. Furthermore, politicians can award low-ranked positions to party brokers in order to sustain party machines. In many develop-

\footnotetext{
${ }^{1}$ See Golden and Min (2013) for a review of the literature on distributive politics and partisan bias in the allocation of public resources.
} 
ing countries party brokers lack the necessary educational background to succeed in high-ranked positions. In short, incumbent politicians in developing democracies can pursue a dual strategy of hiring professional bureaucrats based on meritocratic criteria and menial bureaucrats according to partisan criteria.

To test my argument, I assembly unique data on the universe of over 40,000 bureaucrats working in 200 local governments in Ghana, a stable democracy in West Africa. Such fine-grained data from a developing country are often not available or are very hard to obtain, which is why only a handful of studies has been able to use similar micro-level data. ${ }^{2}$ Electoral politics in Ghana are dominated by the National Democratic Congress (NDC) and the New Patriotic Party (NPP). Since the restoration of democracy, the country's national elections have become increasingly competitive. The NDC won the 2008 presidential election - the focus of this article - by less than half a percent. ${ }^{3}$ In the analysis, I exploit this change in the ruling party to investigate hiring patterns.

The data on bureaucrats include information on the hiring date of each employee. I use the first term (2005-2008) as a baseline for comparison with hiring patterns in the second term (20092012). My study sample consists of all bureaucrats hired during these two terms $(n=17,942)$. If the conventional wisdom of blanket patronage hiring is correct, we would expect the new ruling party to favor its co-partisans for all positions, at the expense of opponents. The data include information on bureaucrats' individual characteristics. In the analysis, I use bureaucrats' ethnicity and home region to proxy for their party. ${ }^{4}$

Disaggregating the data between professional and menial positions, I find no evidence of partisan hiring for professional positions. Professional recruits also become better qualified over time, which suggests a preference for competence. Conversely, a change in ruling party is associated with a 10-percentage-point increase in the probability that a co-partisan will be hired to a menial post. This increase is equivalent to about 635 extra public sector jobs being awarded to

\footnotetext{
${ }^{2}$ The empirical study of bureaucratic recruitment in developing countries is a burgeoning field in political science and economics. Relevant papers include: Hassan (2016); Sigman (2015); Colonnelli, Prem and Teso (2017); Iyer and Mani (2012); Pierskalla and Sacks (2019); Xu (Forthcoming).

${ }^{3}$ The NDC won with 50.2 percent of votes, compared to 49.8 percent for NPP.

${ }^{4}$ In Section 3.2, I discuss how I infer partisanship from these two variables.
} 
government co-partisans, at the cost of over 3 million USD over a four-year term. ${ }^{5}$ Because the data only contain information on local bureaucrats, this bias likely represents a fraction of the aggregate number of partisan hires during the study period. While the analysis does not confirm that such bias led to the appointment of bureaucrats who were not qualified to take menial posts, it does suggest that bureaucrats' identity influenced who the new governing party hired.

My theory suggests that politicians reward party brokers for their support by securing menial jobs for them. I combine quantitative and qualitative data to substantiate this claim. The qualitative evidence suggests that grassroots brokers in Ghana are motivated to work for parties in return for material benefits, including public sector jobs. The data also provide evidence of strategic hiring: politicians allocate more new jobs to districts where brokers attract new voters.

This article makes three contributions. First, the results contribute to the literature on public sector development. It is one of the first empirical studies in political science to use administrative data to document trends in public sector hiring practices in developing countries (see also Hassan, 2016; Pierskalla and Sacks, 2019). My theoretical approach also sheds light on what appear to be inconsistent findings regarding the effect of electoral competition on patronage hiring. While many scholars assert that competition can promote meritocracy (Geddes, 1994; Ting et al., 2013), others find that competition can encourage clientelism, and swell the ranks of the public sector (Pierskalla and Sacks, 2019; Driscoll, 2017; Lindberg, 2003). My theory suggests that electoral competition may have both of these effects: it may dissuade politicians from interfering in hiring for high-ranked positions, while encouraging them to recruit partisans to low-ranked positions.

Second, I advance the literature on measuring meritocracy. Past studies have primarily used either legislation (Geddes, 1994) or surveys of experts or bureaucrats (Kopeckỳ, 2011; Sigman, 2015) to measure this concept. My approach - which combines bureaucrat-level data with a change in the ruling party - is more objective than survey-based methods. Further, the data allow us to analyze de facto practices rather than de jure protocols.

\footnotetext{
${ }^{5}$ The total number of menial hires between 2009 and 2012 was 6,359. See Table C.1. To calculate the cost of 635 bureaucrats, I assume a (conservatively low) monthly salary of 100 USD.
} 
Third, I contribute to the burgeoning empirical literature on party brokers (Calvo and Murillo, 2013; Stokes et al., 2013; Larreguy, Marshall and Querubin, 2016). My work complements prior studies that show brokers often hold public sector positions (Oliveros, 2016), and advances this literature by considering the types of jobs that brokers are likely to hold.

\section{A theory of dual hiring: combining merit and patronage}

Governments in low-income countries dedicate about a third of public budgets to bureaucrats' salaries. ${ }^{6}$ In African countries, the wage bill is often the government's single biggest expense: it represents 55 percent of public expenditure in Kenya, 45 percent in Ghana, and over 33 percent in South Africa. ${ }^{7}$ While the seminal literature on the African state suggests that governments distribute most public sector jobs on the basis of political criteria (Bayart, 1993; Chabal and Daloz, 1999), these claims have not been tested empirically since the re-introduction of multi-party elections in the early 1990s. In this article, I develop a theory of when politicians in developing democracies prioritize meritocratic recruitment over patronage hiring for public sector jobs.

\subsection{The benefits to politicians of distributing low-ranked public sector positions to partisans}

I propose that the costs and benefits of patronage hiring to politicians in developing democracies vary according to the type of public sector job. Certain types of jobs are especially valuable to politicians. In particular, politicians who operate in clientelistic polities will value public sector jobs that they can award to grassroots party brokers. Awarding jobs to brokers has a multiplier effect on votes: the politician gains the support of the broker and her clients. US party leaders used jobs in the postal service and customs houses to build and sustain party machines during the 19th century (Carpenter, 2001). For example in Chicago, political parties distributed jobs to precinct captains who worked to get out the vote and dispense private goods to citizens (Wilson, 1961). ${ }^{8}$

\footnotetext{
${ }^{6}$ See Appendix Table A.1.

${ }^{7}$ On Kenya, see Aljazeera (2014), on Ghana see Africa Confidential (2018), and on South Africa see BusinessTech (2018).

${ }^{8}$ In the US, another major benefit of patronage hiring was the contributions (or assessments) that office holders gave to the party, which constituted 2-10 percent of their salaries (Johnson and Libecap, 1994, 15).
} 
Historical accounts of the US transition towards meritocracy suggest that it took decades for low-ranking jobs outside the capital to be taken out of the hands of politicians. Patronage was sustained for most field positions and top administrative jobs in the capital (Skowronek, 1982, 69). Post offices employing over 50 persons were subject to the Pendleton Act of 1883 . However, in 1896 there were still 76,000 fourth-class postmaster positions that were not covered by the act, and were therefore available for parties to distribute to loyalists (Skowronek, 1982, 72). In contrast, clerical jobs based in the capital were easy for politicians to give up.

The practice of awarding public sector jobs to those who can mobilize voters on behalf of the incumbent party has been documented in other contexts. O'Dwyer (2006) argues that in new Eastern European democracies, citizens were demobilized after years of communist rule such that mass parties with fee-paying memberships are not possible. He maintains that incumbent politicians instead give public sector jobs to party activists (529). Callen, Gulzar and Rezaee (2018) argue that politicians in Pakistan provide patronage to doctors because they act as important political mediators in rural areas at election time. An original survey of party brokers in Argentina shows that 30 percent of brokers have public sector jobs (Stokes et al., 2013, 99). In Africa, scholars argue that politicians create new local-level units precisely so they can distribute new administrative and political positions to local brokers (Hassan and Sheely, 2017) and party supporters (Green, 2010). ${ }^{9}$

While party brokers have significant leadership skills and valuable ties to local elites, in developing countries they are often not particularly well educated. Indeed, many intermediaries work for parties for the material benefits they can extract to supplement their incomes (Bob-Milliar, 2012). A survey of grassroots party brokers in Ghana shows that they are "characteristically very youthful but poorly educated or without formal education" (Bob-Milliar, 2012, 670). Thus politicians can usually only reward them with low-ranked positions. ${ }^{10}$ Because middle-class citizens

\footnotetext{
${ }^{9}$ Similarly, Gottlieb et al. (2018) argue that incumbent parties create new administrative units to co-opt strong community brokers in areas where the party is not already strong. While they do not suggest that local government jobs are distributed directly to brokers, they imply that the incumbent party uses local government units to mobilize votes via community-level brokers.

${ }^{10}$ The jobs that party brokers can reasonably perform will vary according to the country's level of development. In richer countries, where the average level of education will be higher than in poorer countries, brokers may be educated enough to hold mid-ranked positions in the bureaucracy.
} 
with university degrees have fewer financial incentives to work for parties, they are less likely to become brokers. In summary, politicians in developing democracies who want to sustain party machines will seek to exercise control over hiring for low-ranking (menial) jobs in the public sector, which they can use to reward grassroots party brokers.

\subsection{The costs to politicians of distributing high-ranked public sector positions to partisans}

While the benefits of patronage appointments include the ability to extract loyalty and campaign work from public officials, patronage hiring also has at least two important costs. First, it can lead to the inefficient functioning of the state. Second, as the size of the public sector grows, interfering in recruitment processes becomes increasingly time intensive for politicians. These costs to politicians are likely to be greater for high-ranked jobs than for low-ranked jobs, which can incentivize politicians to recruit professional bureaucrats on the basis of meritocratic criteria. ${ }^{11}$ In developing democracies, politicians often retain discretionary control over bureaucrats' careers, which they can leverage to influence their work. Such discretion allows politicians to get the best of both worlds: high levels of competence and loyalty.

As regards state performance, recruiting professional bureaucrats on the basis of partisan, as opposed to meritocratic, criteria can lead to hiring less competent bureaucrats. Partisan recruits are likely to underperform their duties and to be more corrupt (Oliveros and Schuster, 2018). Indeed, meritocratic recruitment has been identified as the most important factor in improving bureaucratic performance (Rauch and Evans, 2000). Bureaucratic underperformance can lead to macro-economic instability and the inefficient delivery of public services. Politicians are likely to be concerned with poor state performance if voters consider government performance when voting.

Evidence suggests that even in relatively clientelistic polities, some voters consider economic management and public service delivery when they vote. The incumbent party's ability to deliver on macro-economic policies has been shown to be an important determinant of vote

\footnotetext{
${ }^{11}$ Throughout, I dichotomize jobs into "low ranked" vs. "high ranked." My argument does not apply to top positions in the public sector such as heads of executive agencies and ambassadors, which remain patronage appointments in most countries (Fisman and Golden, 2017, 39) Unlike other public sector positions, these top-tier jobs are usually not subject to tenure.
} 
choice across the developing world, in Africa (Bratton, Bhavnani and Chen, 2012), Latin America (Roberts and Wibbels, 1999; Lewis-Beck and Ratto, 2013), and Eastern Europe (Roberts, 2008). Performance voting has also been demonstrated in individual African countries such as Zambia (Posner and Simon, 2002), Ghana (Youde, 2005; Lindberg and Morrison, 2008; Hoffman and Long, 2013) and South Africa (Mattes and Piombo, 2001; Ferree, 2006). ${ }^{12}$ Regarding development outcomes, voters prefer politicians who deliver local public infrastructure such as roads, schools, and health clinics (Harding, 2015; Weghorst and Lindberg, 2013; Carlson, 2015; Ofosu, 2018).

Electoral pressures on politicians to deliver development, combined with the difficulty of instituting wholesale meritocratic recruitment practices, can lead politicians to establish bureaucratic "pockets of efficiency" (Geddes, 1994). These national-level agencies operate outside the federal bureaucracy and recruit personnel on the basis of merit (Geddes, 1994, 61). Applying this argument to the local level - the empirical focus of this article - politicians may also have an incentive to recruit competent bureaucrats to work in local governments to efficiently deliver local public goods and services to voters. Given the smaller size of the workforce in local governments, the marginal value of a highly trained bureaucrat is higher in local government offices compared to the national bureaucracy.

Politicians' concerns about the potential electoral reward (or punishment) of better state performance are likely to be intensified in competitive - or increasingly competitive - democratic environments. The positive relationship between electoral competition and the adoption of meritocratic reforms has been demonstrated both theoretically (Geddes, 1991; Ting et al., 2013) and empirically (Geddes, 1994; Grindle, 2012; Ting et al., 2013; Grzymala-Busse, 2007). ${ }^{13}$ Geddes

\footnotetext{
${ }^{12}$ For example, Posner and Simon (2002) find that "regardless of background, respondents who expressed dissatisfaction with the economy were 10-15 percentage points less likely to vote for [President] Chiluba than their more satisfied counterparts" (319). Hoffman and Long (2013) conclude in Ghana that "demographic and ethnic factors are far less important than respondents' beliefs about the parties, candidates, the NPP's performance, and economic conditions" (139).

${ }^{13}$ In contrast to this literature, one can reasonably argue that electoral competition can lead incumbents to prefer an inefficient bureaucracy to an efficient one because, should the incumbents lose office, their opponent can use a highly efficient bureaucracy against them in the future. However, incumbents must weigh this potential should they lose, to the incentive they have to take steps to remain in office. In situations where the likelihood of remaining in office is strengthened by performing well, politicians are likely to prioritize strengthening the state.
} 
(1991) argues that when two political parties are roughly equally popular, it becomes advantageous for the incumbent to adopt reforms in order to capture the electoral benefits of adopting meritocracy. Grzymala-Busse (2007) argues that robust competition leads to monitoring by opponents. As a result, governing parties avoid exploitative state practices to preemptively protect against opposition criticism. In short, electoral incentives can encourage merit-based hiring due to the resulting gains (or losses) in incumbent vote share.

A second cost to politicians of interfering in high-ranked bureaucratic positions is the time it takes to distribute and monitor these appointments. Urbanization and industrialization lead to an increase in the size of the public sector, and bureaucratic tasks become increasingly complex. As the public sector gets larger it becomes more costly for politicians to manage recruitment processes. As the number of positions increases, politicians are required to spend more time ensuring that these positions are filled by loyalists. At some point, the time politicians spend interfering in hiring processes outweighs the benefits. Scholars of the US have argued that the growth in the size of the federal labor force was "[the] overriding factor that changed the way in which federal politicians viewed patronage" (Johnson and Libecap, 1994, 13).

The costs of patronage hiring on politicians' time are likely to be greater for professional positions than for menial jobs. This is because politicians can delegate the recruitment of menial personnel to local party machines, which can identify grassroots brokers who are suitable for these roles. It may be harder for local machines to identify relevant people for professional positions. Instead, politicians can delegate the recruitment of professional bureaucrats to other bureaucrats, who will then organize competitive examinations, develop interview procedures, and establish minimum qualification standards for each job. After bureaucrats have developed rules for meritocratic hiring it becomes more difficult for politicians to intervene. Such interventions are likely to be visible, which can generate criticism from other civil servants, political opponents or from non-governmental organizations, and result in negative media coverage.

Finally, there is an overlooked reason why politicians may have an incentive to prioritize professional competence over partisan loyalty: politicians often continue to be able to influence the 
work of professional bureaucrats even when they do not hire their co-partisans. Empirical research from India and Ghana suggests that politicians may be willing to allow competitive recruitment for professional positions because they know they can still interfere in bureaucrats' careers to influence their behavior (Iyer and Mani, 2012; Brierley, 2018). Despite the existence of highly competitive examinations to enter the top ranks of the civil service in India, for example, politicians continue to influence the actions of civil servants through their control over geographic transfers (Iyer and Mani, 2012; Wade, 1982). Politicians can use transfers, or the threat of transfers, to influence outcomes such as where new local public goods are placed. This suggests that politicians can recruit highly educated professional bureaucrats without stymieing their attempts to politicize the distribution of state resources.

In summary, performance voting incentivizes politicians to develop a preference for hiring competent professionals. This preference will intensify as electoral competition increases because small electoral gains or losses become politically consequential. ${ }^{14}$ Pressure on politicians to delegate bureaucratic recruitment to other bureaucrats will also occur as states become larger and more complex. Because politicians can delegate the recruitment of low-ranked bureaucrats to party machines, pressures on politicians will be more significant for high-ranked positions. Finally, politicians are likely to feel more comfortable delegating recruitment to professional positions to other bureaucrats because they have additional tools - besides hiring - that they can leverage to control the work of bureaucrats once appointed. This paper tests the hypothesis that politicians in clientelistic democracies are more likely to hire public employees on the basis of partisan loyalty for menial jobs rather than for professional positions.

\footnotetext{
${ }^{14}$ It could be argued that improving state performance will raise the expectations of voters, who may then seek to hold incumbents accountable to a greater extent in future electoral rounds. However, in competitive electoral environments where voters have viable alternative options, politicians will have a limited ability to suppress development outcomes because voters will turn to the opposition. Other scholars have highlighted the existence of a robust opposition as an important factor driving politicians' incentives to enhance state capacity (O’Dwyer, 2006; Grzymala-Busse, 2007).
} 


\section{Ghana's electoral environment and scope conditions of the argument}

I evaluate my argument using a novel dataset of bureaucrats who work in local governments in Ghana. Ghana's electoral system has supported three peaceful transitions of executive power (in 2000, 2008, and 2016). Two political parties dominate the electoral landscape, the NPP and NDC. National elections are competitive, and have become increasingly so since democracy was reinstituted in 1992. I focus on the 2008 election, which the NDC won by a margin of less than 0.5 percent of the votes. This election followed two prior elections that saw a significant decrease in the margin of victory of the presidential victor: while in the 2000 election the NPP presidential candidate won by a margin of 14 percent, this dropped to 8 percent in $2004 .{ }^{15}$

My argument of a dual hiring strategy has two central scope conditions. First, politicians must have a preference to govern a state that functions at least reasonably well. This preference encourages them to recruit professional bureaucrats based on non-partisan criteria. This preference is likely to be intensified in competitive electoral environments because the electoral rewards (or punishment) for delivering (not delivering) economic stability or development have greater consequences; incumbents may be ousted. ${ }^{16}$ Second, politicians must mobilize electoral support through grassroots brokers. This condition is likely to hold in developing democracies where parties rely on direct personal contact to rally voters. As organizationally strong political parties are likely to rely more on partisan as opposed to community brokers (Baldwin, 2013; Gottlieb, 2017), the pressure to reward partisan brokers with public sector jobs is expected to be higher in countries with organizationally strong political parties.

Ghana is a case in which there is evidence of performative voting and high levels of electoral competition. Further, both are the two major political parties are organizationally strong and rely on partisan brokers to mobilize support (Ichino and Nathan, 2013; Bob-Milliar, 2012). As regards performance voting, many scholars have argued that in Ghana, "popular evaluations of government performance trump the pervasive tugs of language and tribe" (Bratton, Bhavnani and

\footnotetext{
${ }^{15}$ The NDC won the 2012 election by a margin of 3 percent.

${ }^{16} \mathrm{High}$ levels of electoral competition may be present in countries with both stable and more fluid party systems.
} 
Chen, 2012, 30). For example, Lindberg and Morrison (2008) conduct an open-ended survey and differentiate between evaluative and non-evaluative motivations for vote choice and conclude that "evaluative voting behavior is by far the most common stance in Ghana." Similarly, Jeffries (1998) argues that “The basis for the NDC's victory [in 1996] was laid by its economic and developmental policies," most importantly the Rawlings' government's provision of development projects (205). The influential role of economic performance on voters' attitudes and eventual vote choice has also been demonstrated through quantitative analyses of both the 2000 and 2008 elections (Youde, 2005; Hoffman and Long, 2013).

Political power in Ghana is decentralized to 216 local governments: one local government per district. ${ }^{17}$ Local governments are responsible for the development of districts, including the provision of basic infrastructure and public works and services. The president appoints a District Chief Executive (akin to a mayor) to head each local government, in consultation with the local branch of the ruling party. Thus all mayors are members of the ruling party, regardless of the partisanship of the majority of voters in the district. Each local government has a political and a bureaucratic arm. This articles focuses on the bureaucratic arm. Once appointed, local bureaucrats - in both professional and menial positions - have security of tenure.

\section{Dataset of local bureaucrats and measurement}

The dataset includes employee-level information of civil servants working in 199 of Ghana's 216 local governments ${ }^{18}$ who were in active employment in $2015 .{ }^{19}$ Over 40,000 bureaucrats are included in the data. I restrict the analysis to bureaucrats hired between 2005 and 2012, which leaves a total of 17,942 recruits. The mean number of workers per district is 191 . In theory, all local government employees should be included. While the data are as comprehensive as possible,

\footnotetext{
${ }^{17}$ Local governments are known as District, Municipal or Metropolitan Assemblies, with classifications based on the population of the district.

${ }^{18}$ There is one local government in each district.

${ }^{19}$ These data were compiled by Ghana's Ministry of Local Government and Rural and the Local Government Service Secretariat in partnership with consultants hired by the European Union.
} 
some gaps remain. ${ }^{20}$ To analyze hiring patterns, I use information of the date that each bureaucrat was hired to work in the local bureaucrat. This date reflects the first recruitment date of each bureaucrat.

All candidates for local government jobs are recruited through a centralized hiring pro$\operatorname{cess}^{21}$ that requires candidates to submit a generic application form to the Local Government Secretariat offices in the capital city, Accra. Candidates can submit these applications at any time, but many applicants apply following mass-hiring advertisements that the government places in national newspapers. Interviews with staff at the Local Government Secretariat suggest that mass hiring is the modal type of hiring, as opposed to hiring for individual positions as they become available.

Candidates applying for positions that I code as professional (planning officers, budget officers, engineers, accountants, and economists) are typically recruited using interviews and exams. Candidates recruited to menial positions (sanitation officers, laborers, security guards and drivers) do not sit formal exams. Anecdotal evidence suggests that these candidates are employed through interviews, as well as upon recommendation from local governments to the national secretariat. Recommendations from local governments are prone to partisan influence because mayors are political appointees, and, thus, co-partisan with the national government. In addition to direct recommendations, which likely reveal a candidates partisanship, during the hiring process, politicians and bureaucrats who engage in recruitment can use informational cues - names and home town and region - to infer the likely partisanship of each potential new hire.

\subsection{Measuring levels of meritocracy with administrative data}

I use the bureaucrat data combined with a change in the governing party to assess patronage versus meritocratic hiring. If hiring were purely meritocratic, changes in the governing party should not influence the types of bureaucrats who are hired. Conversely, swings in who gets hired as power

\footnotetext{
${ }^{20}$ One omission is that the top bureaucrat in a district (the district co-ordinating director) is often excluded.

${ }^{21}$ While local governments can recruit temporary workers and pay them using their own internally generated revenues, they are not able to recruit permanent employees.
} 
changes hands would indicate non-merit-based hiring. An additional advantage of using administrative data is that it also permits the disaggregation of civil servants across different departments and different types of positions to investigate which types of jobs or departments are isolated from interference. This approach thus allows me to assess my theory. One challenge of using administrative data is the need to first code the inferred partisanship of each bureaucratic recruit.

\subsection{Coding civil servants' partisanship}

The ideal dataset with which to assess the theory would include the partisanship of each bureaucrat at the time of hiring. However, the act of collecting such data would implicate the government in discriminatory practices, and is therefore unavailable. Instead of relying on a partisanship variable, I use the available data to create two proxies of partisanship. First, I code partisanship using the ethnic group of each bureaucrat. Second, I use their home region. ${ }^{22}$ The former approach complements recent empirical work on bureaucrats in Africa that also uses individuals' ethnic group to determine partisanship (Hassan, 2016). The results that follow are robust to using either measure. ${ }^{23}$ In the main analysis, I focus on the results based on individual ethnicity as this is potentially a more precise categorization of individual partisanship. ${ }^{24}$

As ethnicity was not a variable in the bureaucrat-level data, I coded ethnicity based on the first and last names of each worker. Names were first split into name fragments, which were then coded into one of seven ethnic groupings by multiple research assistants in Ghana. ${ }^{25}$ After matching names to ethnic groupings, I use Afrobarometer survey data to link ethnic groups to

\footnotetext{
${ }^{22}$ Home regions refer to where bureaucrats say they "come from", typically these regions are where individuals have familial roots.

${ }^{23}$ I replicate the results using home region in the Appendix.

${ }^{24}$ For example, the NPP is dominant in the Ashanti region, which is the most populous region the country. While 75 percent of the population in the Ashanti region are Akans (who are aligned with the NPP), 25 percent belong to other ethnic groups. As this example shows, using home region potentially misclassifies individuals.

${ }^{25}$ The ethnic groupings are as follows: Akan (Non-Fante), Akan, Fante, Ewe, Ga-Dangme, Guan and Northern. The dictionary that I create builds on one made by Noah Nathan.
} 
political parties. ${ }^{26}$ Based on these data I code bureaucrats who are Akans as pro-NPP. ${ }^{27}$ I code both Ewe and Northern ethnic groups as being aligned with the NDC. ${ }^{28}$

As regards the second proxy, I identify party strongholds as home regions where the majority of citizens voted for the same party across both elections I analyze. ${ }^{29}$ I code pro-NDC bureaucrats as those whose home region is Northern, Volta, Upper West or Upper East, and pro-NPP bureaucrats as those from either the Ashanti or Eastern regions.

\section{Empirical strategy}

To assess evidence of partisan bias in public sector hiring, I use the change in Ghana's ruling party following the December 2008 elections. The NDC's John Evans Atta-Mills won the 2008 presidential election, and his party won a majority of seats in the parliament. Ghana's alternation in 2008 can be used as a cut point around which to investigate potential changes in bureaucratic hiring. If bureaucrats are recruited on the basis of their partisan ties, we would expect to see significant changes in the partisanship of bureaucrats who were hired after the new party came to power. Specifically, if this is the case, we should expect to find a drop in the share of pro-NPP bureaucrats hired after 2008, and a corresponding increase in the share of pro-NDC bureaucrats hired. My main hypothesis predicts that any increase in pro-NDC hires would be confined to menial positions.

\footnotetext{
${ }^{26}$ Specifically, I use data from rounds 3-6. I do not use data from rounds 1 and 2 because they did not ask which party the respondent would vote for if the election were held tomorrow. I drop respondents who did not answer this question, including those who refused to answer or answered "Don't know".

${ }^{27}$ See Appendix Table E.1.

${ }^{28}$ Ethnicity does not perfectly align with partisanship; not all Akans (Ewes/Northerners) support the NPP (NDC). There could be concern that measurement error biases in favor of finding evidence of patronage hiring in instances in which some Ewe and Northern bureaucrats who are coded as being Pro-NDC are in fact supporters of the opposition. However, there is just as likely to be measurement error in the other direction: some of the Akans hired by the NDC that are coded as NPP supporters will in fact be NDC supporters, leading me to under-estimate patronage hiring. Ex ante, there is no reason to expect that bias in one direction will be more substantial than in the other.

${ }^{29}$ Appendix Table E.2 displays the election results disaggregated by region. The NDC captured the majority of votes in the Volta, Northern, Upper West and Upper East regions, while the NPP received the majority of the votes in the Ashanti and Eastern regions.
} 
To investigate the relationship between bureaucrats' partisanship and the ruling party, I run the following logistic regression model:

$$
\operatorname{logit}\left(p_{i}\right)=\beta_{0}+\beta_{1} \text { Period } 2_{i}+\beta_{2} \text { Menial }_{i}+\beta_{3} \text { Period } 2 * \operatorname{Menial}_{i}+\beta_{4} \mathbf{X}_{i}+\varepsilon_{i}
$$

$P_{i}$ is a dummy variable that takes the value of 1 when the bureaucrat is aligned with the NDC (NPP). Period 2 identifies the second hiring period after the change in the ruling party following the 2008 election. Menial is a dummy variable that takes a value of 1 when the position is low ranking and 0 otherwise. I code positions using information on the job title of each bureaucrat. All positions are classified as either professional or menial.

A summary list of positions and how they are coded is presented in Appendix Table B.1. The process of classifying the positions is subjective. My aim was to code menial positions as those that it would be uncontroversial to describe as such. ${ }^{30}$ Appendix Tables B.2, B.3, B.4 and B.5 show the job titles, frequencies, and coding for all positions. The data also contain information on the gender, age, and highest educational level of each bureaucrat. Thus, $X_{i}$ is a matrix that contains these control variables.

\subsection{Additional information on civil servant database}

While the bureaucrat-level data that I analyze are unusually rich, one drawback is that they were collected at a single point in time (in June 2015). Therefore, I do not have information about bureaucrats who were hired and vacated their positions before the data were collected. ${ }^{31}$ One concern is that pro-NPP bureaucrats hired by the NPP government resigned when the NDC came to power in 2008. The effect of this attrition would be to diminish the likelihood that I would find evidence of partisan hiring under NDC rule. This is because pro-NPP bureaucrats, some of

\footnotetext{
${ }^{30}$ In Appendix Section L, I re-run the analysis varying the classifications of a number of positions where the classification may be considered controversial. The results are robust to these re-classifications. I also conduct the analysis dropping one position at a time to check that the results are not driven by recruitment to a single position; again the results remain robust.

${ }^{31}$ This is the first database of employees working in local governments in Ghana, which makes it impossible to consult older databases.
} 
whom drop out of the data, would appear to compose a smaller share of those hired by the NPP. Correspondingly, pro-NDC bureaucrats would appear to compose a larger share of those hired in the first period.

There are three reasons why this type of attrition might be unlikely. First, civil service jobs are valuable to workers because they offer financial stability in the form of a monthly paycheck, benefits, and an assured pension. Civil servants can also ask politicians for help when they face emergencies. Therefore it is unlikely that an employee would give up their job just because they did not support the new ruling party. Second, while bureaucrats may be unhappy with the change in government, they are likely to anticipate that their preferred party will not be out of office for too long. Indeed, Ghana has seen alternations of power between the two major parties every eight years since its return to democracy in 1992. Third, if it were the case that bureaucrats resigned en masse following the 2008 elections, the data should show a spike in hiring in 2009 (or 2010) to make up for the deficit of workers. Appendix Figure D.1 plots the total number of hires per year between 2005 and 2012 and shows that there were fewer hires in 2009 and 2010 than in 2008. These figures indicate that there was not a mass departure from the bureaucracy after the 2008 election.

\section{Results}

\subsection{Descriptive analyses}

To assess my argument, I first present descriptive data that display the characteristics of bureaucrats hired across the two electoral periods. Second, I conduct a series of logistical regressions that control for a number of important potential confounding variables that may influence hiring.

Table 1 shows the share of NDC and NPP bureaucrats hired in both periods, and presents the results of a difference-in-means test. Bureaucrats' partisanship is coded based on their ethnicity. ${ }^{32}$ The results show a positive and statistically significant increase in the share of NDC bureaucrats

\footnotetext{
${ }^{32}$ Appendix Table H.1 displays the same test with bureaucrats coded by home region. The main result of partisan bias for menial positions is consistent in both tables.
} 
hired to menial positions in the second period (4.57 percentage points, $\mathrm{p}=0.000)$. The results also display a statistically significant reduction in the share of NPP bureaucrats hired for menial positions (-4.80 percentage points). The change in the governing party is not associated with any changes in the share of NDC or NPP bureaucrats hired to professional positions (shown by the insignificant p-values). Overall, the aggregate data lend initial support to the main hypothesis that the NDC government favored its co-partisans when selecting candidates for menial positions. In addition, the new government appears to disfavor NPP bureaucrats for menial positions.

Table 1: Difference-in-means test (ethnic group coding)

\begin{tabular}{llllll}
\hline & & $\begin{array}{l}\text { Period 1 } \\
(\% \text { of hires })\end{array}$ & $\begin{array}{l}\text { Period 2 } \\
(\% \text { of hires })\end{array}$ & Difference & P-value \\
\hline \multirow{2}{*}{ NDC bureaucrat } & Menial & 35.25 & 39.81 & 4.56 & 0.000 \\
& Professional & 33.69 & 32.29 & -1.4 & 0.164 \\
\multirow{2}{*}{ NPP bureaucrat } & Menial & 44.55 & 39.72 & -4.83 & 0.000 \\
& Professional & 48.68 & 48.25 & -0.43 & 0.687 \\
\hline
\end{tabular}

In Figure 1, I categorize bureaucrats into three types: pro-NDC, pro-NPP, and swing. The swing category indicates bureaucrats who do not belong to a politically-aligned ethnic group. ${ }^{33}$ Each plot displays the share of hires in each category per year. The left plot displays trends for professional positions, while the right plot displays trends for menial positions. The dotted lines indicate the change in the ruling party in December 2008.

The plot on the left provides evidence that the partisanship of bureaucrats recruited to professional positions is fairly static across the two electoral periods. Under both governments, the largest share of new hires was from the main ethnic group aligned with the NPP - the Akans. This makes sense because the Akans are the largest single ethnic group in the country. Consistent with Table 1, the change in governing party does not appear to alter hiring patterns for professional jobs.

The right-hand plot in Figure 1 presents the trend for menial positions. In contrast to professional jobs, there was a steady increase in the share of NDC bureaucrats hired for menial

\footnotetext{
${ }^{33}$ The unaligned ethnic groups are Fanti, Ga-Dangme and Guan.
} 
positions after the NDC government was elected at the end of 2008. The size of the increase was 10 percentage points over the period, from 36.5 percent at the start of their term to 46.5 percent by the end of the term. The data also suggest that much of this increase took place at the direct expense of NPP candidates, who experienced a corresponding decline in hires. ${ }^{34}$ When the NPP were in office they also appear to have increasingly hired Pro-NPP and swing bureaucrats to menial positions in the run up to the December 2008 election. This was potentially a strategy to secure their victory or a result of the expectation that they may soon be out of office. In short, the yearly trends complement the aggregate results in Table 1 and suggest partisan hiring for menial positions.

Figure 1: Share of bureaucrat types across two electoral periods (2005-2008, 2009-2012)
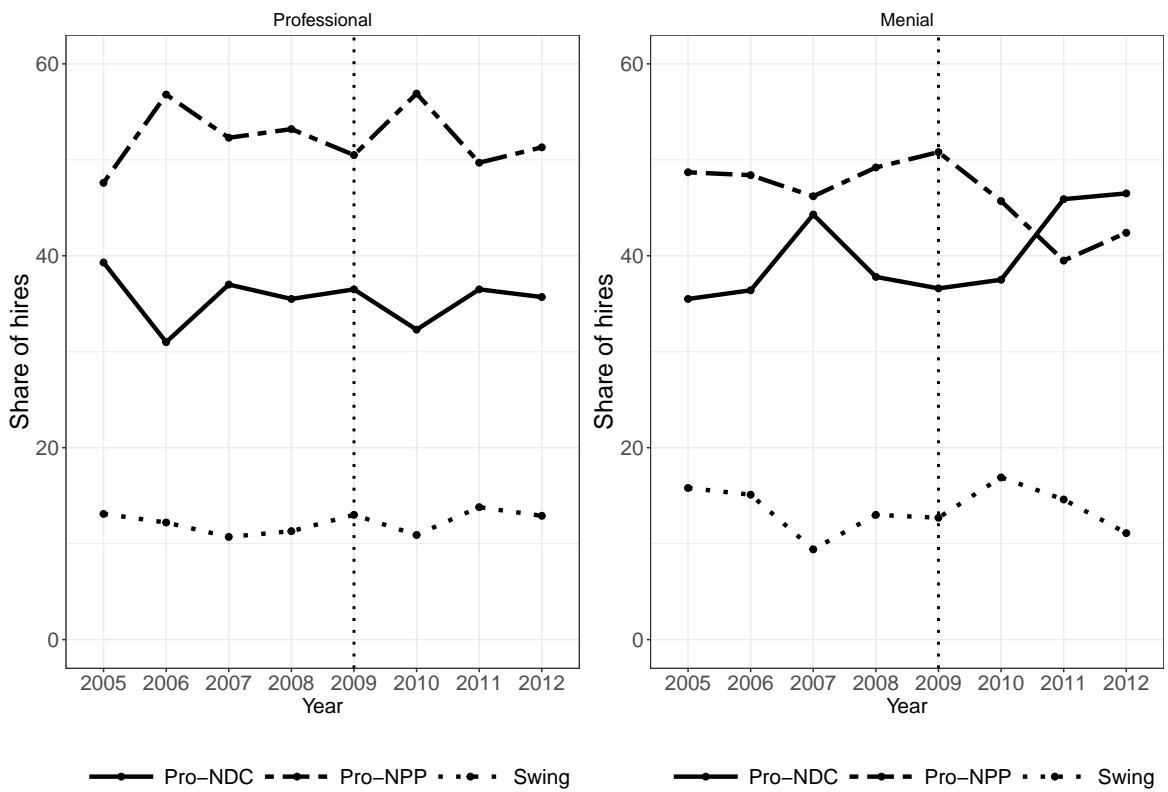

Notes: In Figure 1 employees are categorized as pro-NDC, pro-NPP or Swing. Each plot displays the share of new hires from each group. Bureaucrats are coded according to their ethnic group. The left plot displays trends for professional positions, and the right plot displays trends for menial positions. The dotted line corresponds to the election of the NDC in December 2008.

\footnotetext{
${ }^{34}$ Appendix Figure I.1 displays the same plot with bureaucrats coded according to their home region. The results remain the same, with a sharp increase in bureaucrats with traits that aligned them with the NDC supporters hired after the change in governing party.
} 


\subsubsection{Evidence of meritocratic hiring for professional positions}

The relatively static pattern of hiring among different types of bureaucrats for professional positions across various governing parties suggests that non-partisan criteria drive recruitment to professional positions. Two additional pieces of evidence lend support to the claim that professional bureaucrats are hired on the basis of their merits and suitability for these higher-level positions. ${ }^{35}$

First, professional recruits become increasingly well qualified: the share of new hires who hold bachelor's degrees increases nearly every year from about 8 percent in 1975 to 60 percent in 2012 (see Appendix Figure F.1). Restricting this analysis to the two hiring periods in question, 35 percent of people recruited to jobs coded as professional hired by the NPP government (20042008) held either a bachelor's or master's degree, compared to 55 percent for NDC government hires (2008-2012). This suggests that as access to tertiary education expanded in Ghana, the government recruited increasingly well-qualified applicants.

Second, recruitment through competitive procedures also became increasingly common. A separate survey that I conducted with 864 local bureaucrats in professional positions revealed that the vast majority were selected through competitive processes (Brierley, 2018). ${ }^{36}$ Restricting the analysis to the two hiring periods, 33 percent of bureaucrats hired by the NPP government took a competitive exam, while 92 percent had an interview. This compares to 67 percent who took a competitive exam and 96 percent who had an interview under the NDC government. ${ }^{37}$ Overall, while the results do not point conclusively to meritocracy, they suggest that when the NDC government came to office after the 2008 election, it used increasingly meritocratic hiring criteria to select highly-educated individuals through increasingly competitive procedures.

\footnotetext{
${ }^{35}$ The ideal way to investigate meritocracy is to collect individual-level data on the pool of applicants, as well as data on who is eventually hired. I was not able to obtain data on the pool of applicants across this period of time. To my knowledge, there are no studies of African bureaucracies that perform such an analysis. An important exception in the context of Latin America is Dal Bó, Finan and Rossi (2013), who do obtain data on the applicant pool.

${ }^{36}$ These bureaucrats worked in a random sample of 80 local governments across the country. This survey took place in 2015 and 2016.

${ }^{37}$ I acknowledge that the conduct of interviews and exams does not ensure meritocracy. I do not have data on how candidates performed in these assessments. Furthermore, candidates' performance, especially in interviews, is somewhat subjective. However, the fact that the NDC government hired more candidates following interviews and exams suggests two things. First, it suggests a move towards meritocracy. Second, the delegation of hiring processes from politicians to bureaucrats: bureaucrats conduct these processes and evaluate candidates.
} 


\subsection{Regression analyses}

A series of regression analyses adds further credibility to the results presented above (Table 2). In these models, the dependent variables are dummy variables that indicate bureaucrats' partisan type. Column 1 predicts pro-NDC bureaucrats, Column 2 predicts swing bureaucrats, and 3 predicts pro-NPP bureaucrats. The two main explanatory variables are a dummy variable that distinguishes between the two hiring periods - the change in ruling party - and an indicator of whether the job is menial. A positive coefficient on the interaction term would indicate that the new ruling party distributed more menial than professional posts to their co-partisans. In these models, I hold constant gender, age, and highest level of education. ${ }^{38}$

In Column 1, the coefficient on the variable that indicates a change in the ruling party is negative. This suggests that a change in the ruling party is associated with an overall decrease in the likelihood of a pro-NDC bureaucrat being hired to a professional position. The next coefficient indicates the relationship between menial jobs and being a pro-NDC bureaucrat; it is also negative. The coefficient on the interaction term is the key quantity of interest. The positive sign on this term shows that the change in government is associated with an increase in the likelihood of a pro-NDC bureaucrat being hired for a menial position. This coefficient is statistically significant below the 1 percent level. Figure 2 illustrates the substantive significance of this result.

Column 2 displays the results of the same model specification with Swing bureaucrats as the dependent variable. None of the coefficients are statistically significant, which suggests that the change in the ruling party did not affect hiring patterns for politically non-aligned bureaucrats.

Finally, Column 3 displays the results of the same model specification with Pro-NPP bureaucrats as the dependent variable. The first coefficient is positive, although not statistically significant. This suggests that the NDC government did not demonstrate partisan bias when recruiting professionals; they continued to hire pro-NPP bureaucrats into these positions. However, there is

\footnotetext{
${ }^{38}$ Many bureaucrats did not indicate their highest level of education. In the Appendix, I present the same results controlling only for gender and age, and the results remain the same. In Table J.1 the number of observations increases by roughly 8,000 bureaucrats.
} 
Table 2: Logistic regression predicting hiring of partisan bureaucrats across each time period

\begin{tabular}{lccc}
\hline \hline & \multicolumn{3}{c}{ Dependent variable: } \\
\cline { 2 - 4 } & NDC bureaucrat & Swing bureaucrat & NPP bureaucrat \\
& $(1)$ & $(2)$ & $(3)$ \\
\hline Change in ruling party & $-0.154^{* * *}$ & 0.119 & 0.083 \\
& $(0.059)$ & $(0.092)$ & $(0.056)$ \\
Menial & -0.129 & 0.202 & 0.010 \\
& $(0.094)$ & $(0.135)$ & $(0.084)$ \\
Change in ruling party * menial & $0.614^{* * *}$ & -0.187 & $-0.434^{* * *}$ \\
& $(0.103)$ & $(0.150)$ & $(0.094)$ \\
\hline Observations & & & 9,780 \\
Log Likelihood & 9,780 & 9,068 & $-6,725.204$ \\
\hline \hline Note: & $-6,111.116$ & $-3,284.289$ & \multicolumn{3}{c}{$\mathrm{p}<0.1 ;{ }^{* *} \mathrm{p}<0.05 ;{ }^{* * *} \mathrm{p}<0.01$}
\end{tabular}

Notes: The regressions control for gender, age at time of hiring, and highest level of education. Bureaucrats' partisanship is coded according to their ethnicity. The change in the ruling party follows Ghana's December 2008 election, which resulted in the NDC coming to office. ${ }^{*} \mathrm{p}<0.1 ;{ }^{* *} \mathrm{p}<0.05$; ${ }^{* * *} \mathrm{p}<0.01$.

a negative and statistically significant coefficient on the interaction term, which suggests that NPP bureaucrats were less likely to be hired for menial positions.

Figure 2 displays the substantive significance of the results. I calculate the predicted probabilities of a pro-NDC bureaucrat being hired to (a) a professional position and (b) a menial position in the two time periods. Figure 2 shows the difference in these predicted probabilities and the associated 95 percent confidence intervals.

The top plot in Figure 2 demonstrates that the change in government is not associated with a change in the likelihood of pro-NDC workers being hired for professional positions. In other words, there is no evidence of discriminatory partisan hiring for professional jobs. In contrast, proNDC bureaucrats were 10 percentage points more likely to be hired for menial positions after the NDC came to power at the end of 2008. These results support the first hypothesis and demonstrate that the regression results are substantively important.

The bottom plot in Figure 2 suggests that when the NDC was in power, it was less likely to hire pro-NPP bureaucrats to menial positions. The change in predicted probabilities is about 
Figure 2: Difference in the predicted probability of a pro-NDC and pro-NPP bureaucrat being hired in each term, disaggregated by job type.
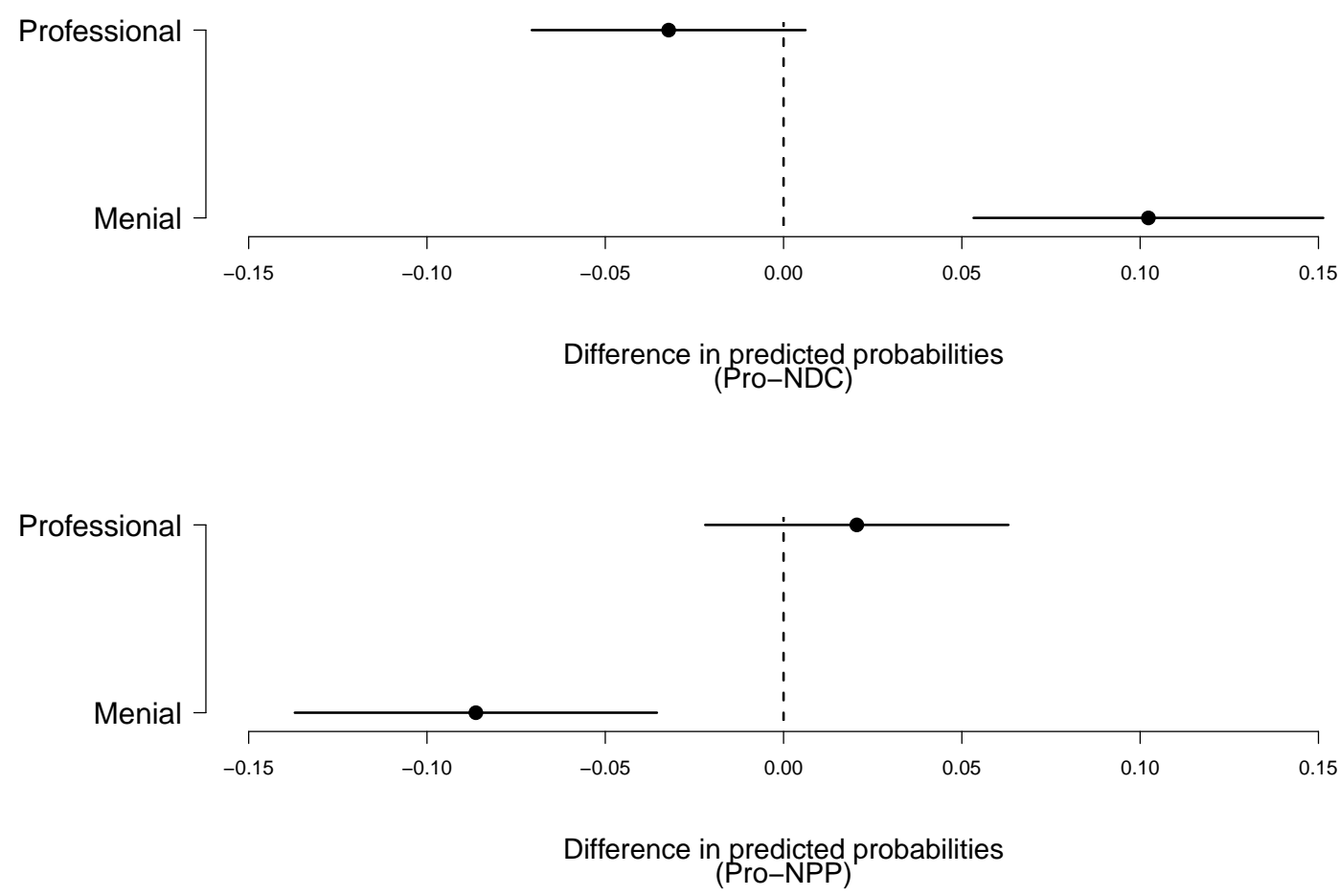

Notes: Figure 2 displays the difference in the predicted probabilities of a pro-NDC/pro-NPP bureaucrat being hired over the two time periods (2005-2008 and 2009-2012). I disaggregate job types into professional and menial positions. I calculate these predicted probabilities using the coefficients in Columns (1) and (2) of Table 2.

8 percentage points. The NDC government was neither more nor less likely to hire pro-NPP bureaucrats for professional positions. In summary, the results suggest that the partisanship of bureaucrats did not influence who got hired for professional positions, but did influence selection into menial positions.

An alternative argument to the one that I present is that, besides the change in ruling party, something else occurred that affected hiring patterns. Experts on Ghanaian politics, for example, might point to the creation of 32 new districts, and corresponding local governments, in February 
2008 (10 months before the election). ${ }^{39}$ If these new districts were concentrated in areas where the NDC were electorally dominant, one could argue that the new ruling party were disproportionately hiring Pro-NDC bureaucrats into menial positions to staff these new local offices. However, this argument is an unlikely explanation of the results because the new districts were not concentrated in regions that I code as being Pro-NDC. Indeed, only ten of the new local governments (28 percent) were in the three northern regions or in Volta region.

A similar change occurred in 2012, when the NDC government created another 46 districts. In this case, a larger share of the new local governments were in the regions that I code as being Pro-NDC (44 percent). As a robustness check, I re-run the analysis dropping all hires made after 28th June 2012 (the date the new districts were created). The results are robust to this specification (see Appendix Table J.3).

Another rival argument is that the patterns I find result from an under supply of available educated citizens from ethnic groups that are aligned with the NDC government. This would imply that the NDC government had no choice but to hire educated citizens from either non-aligned ethnic groups or from groups aligned to the NPP. Appendix Table G.1 displays evidence that there was a roughly equal available supply of highly educated citizens aligned with either party. Specifically, I estimate that there were a total of approximately 247,470 NDC-aligned citizens with higher levels of education compared to 271,700 NPP-aligned citizens. The NDC government recruited a total of 5,940 professionals into the local bureaucrats during their first term in office after the 2008 election (see Appendix Table C.1). Thus, the data suggest that had the NDC wanted to hire co-partisans to these positions there was a large enough supply of competent individuals. ${ }^{40}$

\footnotetext{
${ }^{39}$ The total number of districts went from 138 to 170 (see Ayee, 2013).

${ }^{40} \mathrm{~A}$ final rival argument is that the patterns that I find are the result of changes in the supply of recruits, rather than a change in demand for certain types of workers. However, given the immense value of having a public sector job, and the fact that individuals do not have to pay to apply, I do not expect that pro-NPP recruits would stop applying after the change in government.
} 


\subsection{Evidence that menial positions are given to party intermediaries}

The above results suggest that the new NDC government recruited co-partisans into menial positions after they came to office in 2008. In this section, I present quantitative and qualitative evidence that politicians in Ghana reward party brokers with menial positions in the public sector, including in local governments.

\subsubsection{What motivates party intermediaries to work for the party machine?}

Citizens in Ghana believe that brokers work for parties in return for material benefits. A countryspecific question in the 2012 Afrobarometer asked citizens why they thought party intermediaries work for parties. Roughly 60 percent of Ghanaians responded that they do so because "they expect material rewards after winning political power" (Ghana Center for Democratic Development, 2017). ${ }^{41}$ The brokers themselves admit that they work for parties because of the selective incentives they offer, including jobs (Bob-Milliar, 2012). Bob-Milliar (2012) explains, "Throughout the Fourth Republic, party foot-soldiers have demanded openly to be rewarded by their respective parties for their activism" (677). Pertinent to this article is whether menial jobs in local governments are rewarded to party intermediaries.

I subset the data to analyze the share of pro-NDC hires to various menial positions between 2008 and 2012. Positions that had large shares of co-partisans include environmental assistants (65 percent of all hires), watch guards (55 percent) and disaster management officers (39 percent). ${ }^{42}$ These findings are consistent with accounts from Ghanaian scholars and journalists who have also noted, for example, that local disaster management jobs are often distributed to party intermediaries. One reporter explains that disaster management "has been known to be a den for political appointees with governments recruiting its supporters to the organization even though they have little or no experience in disaster management" (My Joy Online, 2017). In summary, the results

\footnotetext{
${ }^{41}$ In comparison, about one-third (31 percent), believe brokers toil for their party because "they believe in their programs."

${ }^{42}$ See Appendix Table M.1.
} 
are consistent with scholarly and journalistic accounts, as well as with public opinion, that parties in Ghana reward intermediaries with low-ranked public sector jobs.

\subsubsection{What types of districts get menial hires?}

The literature on patronage suggests that parties distribute public sector jobs to loyal supporters as rewards for their work in getting out the votes (Robinson and Verdier, 2013). If politicians do distribute jobs as rewards we might expect to see more menial hires in districts where the party experienced significant increases in their vote share compared to the prior election. Such a result would indicate that the incumbent party is strategic in their distribution of appointments; rewarding brokers who brought them votes.

The results support this interpretation of menial jobs being distributed as rewards. Table 3 displays a positive correlation between the number of menial hires and district-level changes in the vote share of the NDC. The data are aggregated at the district level, such that the dependent variable is the number of menial hires per district. The data are restricted to the four-year electoral term after the NDC came to power following the December 2008 election in order to analyze hires made by the NDC government. ${ }^{43}$ The main independent variable is the change in the vote share of the incumbent party between the 2004 and 2008 elections.

The first three columns in Table 3 consider all menial hires. The last three columns consider menial hires who belong to ethnic groups aligned with the ruling party. All regressions include region fixed effects. Column (1) shows a positive and statistically significant association between change in the ruling party vote share and the number of menial hires. Column (4) also shows a positive association between change in ruling party vote share and the number of Pro-NDC hires, although this coefficient is not statistically significant. ${ }^{44}$ Columns (2) and (4) control for both the type of local government and the population of the district. ${ }^{45}$ Including these variables

\footnotetext{
${ }^{43}$ There is significant variation in the number of menial hires per district, ranging from 1 to 613 recruits, with a mean of 29 and a median of 22 per district.

${ }^{44}$ The $p$-value on this coefficient is 0.17 .

${ }^{45}$ Local governments in Ghana are categorized as District, Municipal or Metropolitan Assemblies based on the population of the district.
} 
significantly improves the fit of the model, and these variables are highly predictive: Municipal and Metropolitan districts have more hires. ${ }^{46}$ In columns (5) and (6) the coefficient on change in NDC votes share also becomes statistically significant (at the 0.1 level). Columns (3) and (6) also include the share of houses with electricity, which serves as a proxy for urbanization. Again, the coefficient of interest remains significant and positive. Substantively, the results suggest that a district where the party saw a 10 percentage point increase in vote share would get 5 more menial hires than a district that saw a 10 percentage point decrease in ruling party vote share (see Appendix Figure Q.1 for a plot of the marginal effect of vote share). Overall, this analysis points to the strategic allocation of menial hires to reward party intermediaries who rallied support for the new incumbent party. $^{47}$

\subsubsection{Is there evidence that menial recruits are embedded in the communities they are hired to work in?}

Finally, I focus on one characteristic of party brokers that is essential for them to perform their roles - their embeddedness in the community. I use the distance each officer works from her hometown as a proxy for entrenchment. I assess whether bureaucrats in menial positions work in local governments closer to their home towns than bureaucrats in professional positions. To clarify, each district has one set of local government offices where all bureaucrats work. These offices are located in the district capitals. Thus, workplace locations are constant across both groups of bureaucrats. Working close to one's hometown is not sufficient evidence that a bureaucrat in a menial position is a broker. However, it is likely to be a necessary condition, and thus evidence of a difference in the distances to hometowns for professional and menial bureaucrats lends further credibility to my argument.

I use the hometown variable in the dataset to identify the town that bureaucrats view as their "home", which typically refers to the place where they have familial roots. I geocode the locations

\footnotetext{
${ }^{46}$ The negative coefficient on the population coefficient is most likely because the type of local government already accounts for the variation in population across districts.

${ }^{47}$ Appendix Table P.1 presents the same analyses with Pro-NPP hires as the dependent variable. These results show that there is no relationship between the change in NDC vote share and the number of Pro-NPP hires.
} 
Table 3: Predictors of the number of menial hires (2009-2012)

\begin{tabular}{|c|c|c|c|c|c|c|}
\hline & \multicolumn{6}{|c|}{ Dependent variable } \\
\hline & \multicolumn{6}{|c|}{ Number of menial hires } \\
\hline & \multicolumn{3}{|c|}{ Total hires } & \multicolumn{3}{|c|}{ Pro-NDC hires } \\
\hline & (1) & $(2)$ & (3) & (4) & $(5)$ & $(6)$ \\
\hline$\Delta$ in NDC vote share & $\begin{array}{c}36.146^{* *} \\
(16.660)\end{array}$ & $\begin{array}{l}24.995^{* *} \\
(10.595)\end{array}$ & $\begin{array}{l}22.492^{* *} \\
(10.807)\end{array}$ & $\begin{array}{c}18.471 \\
(13.391)\end{array}$ & $\begin{array}{l}10.453^{*} \\
(6.080)\end{array}$ & $\begin{array}{l}12.215^{*} \\
(6.180)\end{array}$ \\
\hline Metropolitan & & $\begin{array}{c}168.005^{* * *} \\
(12.578)\end{array}$ & $\begin{array}{c}165.177^{* * *} \\
(12.805)\end{array}$ & & $\begin{array}{c}161.024^{* * *} \\
(7.136)\end{array}$ & $\begin{array}{c}163.029^{* * *} \\
(7.246)\end{array}$ \\
\hline Municipal & & $\begin{array}{c}16.318^{* * *} \\
(2.359)\end{array}$ & $\begin{array}{c}15.576^{* * *} \\
(2.444)\end{array}$ & & $\begin{array}{c}8.473^{* * *} \\
(1.345)\end{array}$ & $\begin{array}{c}8.978^{* * *} \\
(1.386)\end{array}$ \\
\hline $\log$ (Population) & & $\begin{array}{l}-3.328 \\
(2.038)\end{array}$ & $\begin{array}{c}-4.164^{*} \\
(2.163)\end{array}$ & & $\begin{array}{l}-1.526 \\
(1.169)\end{array}$ & $\begin{array}{l}-0.901 \\
(1.244)\end{array}$ \\
\hline Electricity share & & & $\begin{array}{c}8.799 \\
(7.688)\end{array}$ & & & $\begin{array}{l}-6.326 \\
(4.417)\end{array}$ \\
\hline Region fixed effects & Yes & Yes & Yes & Yes & Yes & Yes \\
\hline Observations & 157 & 157 & 157 & 152 & 152 & 152 \\
\hline $\mathrm{R}^{2}$ & 0.151 & 0.667 & 0.670 & 0.254 & 0.851 & 0.853 \\
\hline Adjusted $\mathrm{R}^{2}$ & 0.093 & 0.637 & 0.638 & 0.201 & 0.837 & 0.838 \\
\hline
\end{tabular}

Notes: The unit of analysis is the district. Change in NDC vote share is measured between the 2004 and 2008 elections using constituency-level data from the parliamentary elections. The control variables (population and electricity share) are from Ghana's 2010 Housing and Population Census. ${ }^{*} \mathrm{p}<0.1$; ${ }^{* *} \mathrm{p}<0.05 ;{ }^{* * *} \mathrm{p}<0.01$

of district capitals and home towns and calculate the distance between the two for each bureaucrat in the data. ${ }^{48}$ The results show that the median distance between home town and work location is significantly lower for bureaucrats in menial compared to professional positions. ${ }^{49}$ The median distance from their hometown is $36 \mathrm{~km}$ for menial and $92 \mathrm{~km}$ for professional jobs. ${ }^{50}$ Appendix Figure O.1 focuses on a few select positions to further demonstrate these differences. The results show that budget officers, planning officers and assistant directors work, on average, much farther from their home communities than drivers, laborers and disaster management assistants. The median distance from hometown is $19 \mathrm{~km}$ for laborers, $21 \mathrm{~km}$ for drivers, and $28 \mathrm{~km}$ for disaster

\footnotetext{
${ }^{48}$ I geo-code locations using search requests to the Google Maps API using the ggmap package in R. Google Maps does not include every town in Ghana. I obtain complete matches (i.e., both hometown and district capital) for 74 percent of the bureaucrats hired in the study period ( $\mathrm{N}=13,283$ bureaucrats).

${ }^{49}$ See Appendix Figure N.1.

${ }^{50}$ Given the skewed distribution, the median is the most appropriate measure of average trends.
} 
assistants, compared to $151 \mathrm{~km}$ for budget officers, $161 \mathrm{~km}$ for planning officers and $174 \mathrm{~km}$ for assistant directors.

These results lend further credence to my theory in two ways. First, they show that bureaucrats working in professional positions are unlikely to be party brokers, suggesting instead that they are hired based on non-partisan criteria. Second, and conversely, the results provide evidence that bureaucrats in menial positions could work as party intermediaries. Working close to one's hometown allows partisan recruits to mobilize support for the incumbent by utilizing their social ties with local communities and local party elites. Brokers employed in the district government may be particularly effective intermediaries, as they can help citizens access the state, and can distribute state resources to local voting blocs (Auerbach and Thachil, Forthcoming).

\section{Conclusion}

The improvement of bureaucratic competence is essential to enhancing state capacity in developing democracies. Accordingly, who the state hires into the public sector has broad implications for development. Many governments spend the bulk of public expenditure on public sector salaries. This article assesses meritocratic versus patronage hiring in the context of Ghana. I theorize that the costs to politicians of competitive hiring are not constant across positions. Conceptualizing meritocracy as a continuous variable, I do not ask whether jobs are distributed on the basis of merit, but which jobs are awarded competitively. I theorize that politicians in clientelistic democracies will be more willing to relinquish control over hiring for professional jobs than they will be for low-ranked positions in the public sector. Politicians reward party brokers who mobilize on their behalf with these menial jobs.

I analyze an original individual-level dataset on the universe of bureaucrats working across about 200 local governments in Ghana. As party affiliation is not a variable in the dataset, I code bureaucrats' partisanship based on their ethnicity and home region. I use a change in the ruling party following Ghana's 2008 elections to compare patterns of hiring under two opposing parties. The results suggest that politicians are more likely to interfere in hiring for menial jobs 
than professional jobs: there is a 10-percentage-point increase in the probability of a co-partisan being hired to a menial position after the change in government.

My theory highlights the problems of using legislation to measure meritocracy (Geddes, 1994; Ting et al., 2013). Merit legislation has been shown to be neither necessary nor sufficient to ensure non-partisan hiring recruitment (Schuster, 2017). Indeed, weak rule-of-law and legal loopholes mean that politicians regularly make partisan appointments in spite of merit laws (Meyer-Sahling, 2006). The results suggest the need for continuous measures of patronage and meritocracy. As an alternative to a legislative analysis, I propose measuring levels of patronage using administrative data on the composition of public workforces.

The findings also shed light on the mixed results in the literature on the effect of competition on patronage hiring. Driscoll (2017) finds that electorally competitive districts have more local government employees in Ghana. He similarly argues that politicians exchange these - mainly lowranked - positions with party activists. Pierskalla and Sacks (2019) shows that the introduction of elections increased the number of teachers employed in Indonesia. In contrast, much of the seminal literature on the state suggests that electoral competition can constrain runaway state building and incentivize politicians to support meritocracy (O’Dwyer, 2006; Geddes, 1994). My results suggest that electoral competition can have both of these effects.

This study has significant implications for future research on the public sector. As new data become available, it would be fruitful to replicate the analysis in other contexts. Similar bureaucrat-level data can be used to assess meritocracy in other countries, and across different public sector departments. Importantly, my results suggest the need to distinguish between different types of jobs in such analyses in order to assess more nuanced hypotheses regarding the effects of democracy on meritocratic versus patronage hiring practices. 
Acknowledgements: For helpful comments, I thank Brian Crisp, Stefano Fiorin, Barbara Geddes, Mai Hassan, Martha Johnson, Noah Nathan, George Ofosu, Jan Pierskalla, Dan Posner, Margit Tavits, Mike Thies, Daniel Triesman, Andrea Vilán, and Martha Wilfahrt. I also thank my anonymous reviewers for their feedback. Previous versions of this manuscript were presented at the African Studies Association Annual Conference in November, 2017, the Data Driven Development for Africa workshop at Indiana University in May, 2018, and the American Political Science Association Annual Conference in November, 2018. For sharing their data, I thank the Local Government Service Secretariat in Accra. I am also grateful to Gangyi Sun for excellent research assistance. 


\section{References}

Africa Confidential. 2018. "Tax and spend dilemmas.".

URL: https://www.africa-confidential.com/article/id/12322/Tax_and_spend_dilemmas

Aljazeera. 2014. "Kenya's wage bill dilemma.”.

URL: https://www.aljazeera.com/blogs/africa/2014/03/98646.html

Auerbach, Adam and Tariq Thachil. Forthcoming. "How Clients Select Brokers: Competition and Choice in India's Slums." American Political Science Review .

Ayee, Joseph RA. 2013. "The political economy of the creation of districts in Ghana." Journal of Asian and African Studies 48(5):623-645.

Baldwin, Kate. 2013. "Why vote with the chief? Political connections and public goods provision in Zambia." American Journal of Political Science 57(4):794-809.

Bayart, Jean-Francois. 1993. The State in Africa: The Politics of the Belly. London: Longman.

Bob-Milliar, George M. 2012. "Political party activism in Ghana: factors influencing the decision of the politically active to join a political party.” Democratization 19(4):668-689.

Bratton, Michael, Ravi Bhavnani and Tse-Hsin Chen. 2012. "Voting intentions in Africa: ethnic, economic or partisan?" Commonwealth \& Comparative Politics 50(1):27-52.

Brierley, Sarah. 2018. "Unprincipled Principals: Co-opted Bureaucrats and Corruption in Ghana." Working Paper.

BusinessTech. 2018. "Government's insane wage bill.”. URL: https://businesstech.co.za/news/government/235879/governments-insane-wage-bill/

Callen, Michael, Saad Gulzar and Arman Rezaee. 2018. "Can Political Alignment be Costly?" Working paper .

Calvo, Ernesto and Maria Victoria Murillo. 2013. "When Parties Meet Voters Assessing Political Linkages Through Partisan Networks and Distributive Expectations in Argentina and Chile." Comparative Political Studies 46(7):851-882.

Carlson, Elizabeth. 2015. "Ethnic voting and accountability in Africa: A choice experiment in Uganda." World Politics 67(2):353-385.

Carpenter, Daniel P. 2001. The forging of bureaucratic autonomy: Reputations, networks, and policy innovation in executive agencies, 1862-1928. Princeton University Press.

Chabal, Patrick and Jean-Pascal Daloz. 1999. Africa works: the political instrumentalization of disorder. Indiana University Press Indiana.

Clements, Benedict J. 2010. Evaluating government employment and compensation. Vol. 10 International Monetary Fund. 
Colonnelli, Emanuele, Mounu Prem and Edoardo Teso. 2017. "Patronage in the Allocation of Public Sector Jobs.” Working Paper.

Dal Bó, Ernesto, Frederico Finan and Martín A Rossi. 2013. "Strengthening state capabilities: The role of financial incentives in the call to public service." The Quarterly Journal of Economics 128(3):1169-1218.

Driscoll, Barry. 2017. "Why Political Competition Can Increase Patronage.” Studies in Comparative International Development pp. 1-24.

Ferree, Karen E. 2006. "Explaining South Africa's racial census." The Journal of Politics 68(4):803-815.

Fisman, Raymond and Miriam A Golden. 2017. Corruption: What everyone needs to know. Oxford University Press.

Geddes, Barbara. 1991. "A Game Theoretic Model of Reform in Latin American Democracies." The American Political Science Review 85(2):pp. 371-392.

Geddes, Barbara. 1994. Politician's dilemma: building state capacity in Latin America. University of California Press.

Ghana Center for Democratic Development. 2017. "Elections Policy Brief (No. 4) - Political party vigilantism.".

Golden, Miriam and Brian Min. 2013. "Distributive politics around the world." Annual Review of Political Science 16:73-99.

Gottlieb, Jessica. 2017. "Explaining Variation in Broker Strategies: A Lab-in-the-Field Experiment in Senegal." Comparative Political Studies 50(11):1556-1592.

Gottlieb, Jessica, Guy Grossman, Horacio A Larreguy and Benjamin Marx. 2018. "A Signaling Theory of Distributive Policy Choice: Evidence From Senegal." Jounal of Politics .

Green, Elliott. 2010. "Patronage, district creation, and reform in Uganda." Studies in comparative international development 45(1):83-103.

Grindle, Merilee S. 2012. Jobs for the Boys: Patronage and the State in Comparative Perspective. Harvard University Press.

Grzymala-Busse, Anna. 2007. Rebuilding Leviathan: Party competition and state exploitation in post-communist democracies. Cambridge University Press.

Harding, Robin. 2015. "Attribution and accountability: Voting for roads in Ghana.” World Politics 67(04):656-689.

Hassan, Mai. 2016. "The Strategic Shuffle: Ethnic Geography, the Internal Security Apparatus, and Elections in Kenya." American Journal of Political Science 61(2):382-395. 
Hassan, Mai and Ryan Sheely. 2017. "Executive-Legislative Relations, Party Defections, and Lower Level Administrative Unit Proliferation: Evidence From Kenya." Comparative Political Studies 50(12):1595-1631.

Hoffman, Barak D and James D Long. 2013. "Parties, ethnicity, and voting in African elections." Comparative Politics 45(2):127-146.

Ichino, Nahomi and Noah L Nathan. 2013. "Do Primaries Improve Electoral Performance? Clientelism and Intra-Party Conflict in Ghana." American Journal of Political Science 57(2):428-441.

Iyer, Lakshmi and Anandi Mani. 2012. "Traveling agents: political change and bureaucratic turnover in India." Review of Economics and Statistics 94(3):723-739.

Jeffries, Richard. 1998. "The Ghanaian elections of 1996: towards the consolidation of democracy?" African affairs 97(387):189-208.

Johnson, Ronald N and Gary D Libecap. 1994. The Federal Civil Service System and the Problem of Bureaucracy. University of Chicago Press.

Kopeckỳ, Petr. 2011. "Political competition and party patronage: Public appointments in Ghana and South Africa." Political Studies 59(3):713-732.

Larreguy, Horacio, John Marshall and Pablo Querubin. 2016. "Parties, Brokers, and Voter Mobilization: How Turnout Buying Depends Upon the Party's Capacity to Monitor Brokers." American Political Science Review 110(1):160-179.

Lewis-Beck, Michael S and María Celeste Ratto. 2013. "Economic voting in Latin America: A general model." Electoral Studies 32(3):489-493.

Lindberg, Staffan I. 2003. “'It's Our Time to "Chop"': Do Elections in Africa Feed NeoPatrimonialism rather than Counter-Act It?" Democratization 10(2):121-140.

Lindberg, Staffan I and Minion KC Morrison. 2008. "Are African voters really ethnic or clientelistic? Survey evidence from Ghana.” Political Science Quarterly 123(1):95-122.

Mattes, Robert and Jessica Piombo. 2001. "Opposition parties and the voters in South Africa's general election of 1999." Democratization 8(3):101-128.

Meyer-Sahling, Jan-Hinrik. 2006. "The Institutionalization of Political Discretion in PostCommunist Civil Service Systems: The Case of Hungary." Public Administration 84(3):693715 .

My Joy Online. 2017. "Over 80 percent of NADMO staff have no training - outgoing NADMO boss.".

URL: https://www.myjoyonline.com/news/2017/March-18th/over-80-of-nadmo-staff-have-notraining-outgoing-nadmo-boss.php

O’Dwyer, Conor. 2006. Runaway state-building: Patronage politics and democratic development. John Hopkins University Press. 
Ofosu, George. 2018. "Do Fairer Elections Increase the Responsiveness of Politicians?" Working paper.

Oliveros, Virginia. 2016. "Making it personal: Clientelism, favors, and the personalization of public administration in Argentina." Comparative Politics 48(3):373-391.

Oliveros, Virginia and Christian Schuster. 2018. "Merit, tenure, and bureaucratic behavior: Evidence from a conjoint experiment in the Dominican Republic." Comparative Political Studies 51(6):759-792.

Pierskalla, Jan H and Audrey Sacks. 2019. "Personnel Politics: Elections, Clientelistic Competition and Teacher Hiring in Indonesia.” British Journal of Political Science pp. 1-23.

Posner, Daniel N and David J Simon. 2002. "Economic conditions and incumbent support in Africa's new democracies: evidence from Zambia." Comparative Political Studies 35(3):313336.

Rauch, James E and Peter B Evans. 2000. "Bureaucratic structure and bureaucratic performance in less developed countries." Journal of public economics 75(1):49-71.

Roberts, Andrew. 2008. "Hyperaccountability: economic voting in Central and Eastern Europe." Electoral studies 27(3):533-546.

Roberts, Kenneth M and Erik Wibbels. 1999. "Party systems and electoral volatility in Latin America: a test of economic, institutional, and structural explanations." American Political Science Review 93(3):575-590.

Robinson, James A and Thierry Verdier. 2013. “The Political Economy of Clientelism.” The Scandinavian Journal of Economics 115(2):260-291.

Schuster, Christian. 2017. "Legal reform need not come first: Merit-based civil service management in law and practice." Public Administration 95(3):571-588.

Sigman, Rachel. 2015. Which Jobs for Which Boys? Patronage for Political Finance. Working paper.

Skowronek, Stephen. 1982. Building a new American state: The expansion of national administrative capacities, 1877-1920. Cambridge University Press.

Stokes, Susan C, Thad Dunning, Marcelo Nazareno and Valeria Brusco. 2013. Brokers, Voters, and Clientelism: The Puzzle of Distributive Politics. Cambridge University Press.

Ting, Michael M, James M Snyder, Shigeo Hirano and Olle Folke. 2013. "Elections and reform: The adoption of civil service systems in the US states." Journal of Theoretical Politics 25(3):363-387.

Van de Walle, Nicolas. 2001. African economies and the politics of permanent crisis, 1979-1999. Cambridge University Press. 
Wade, Robert. 1982. "The system of administrative and political corruption: Canal irrigation in South India." The Journal of Development Studies 18(3):287-328.

Weghorst, Keith R and Staffan I Lindberg. 2013. "What Drives the swing voter in Africa?" American Journal of Political Science 57(3):717-734.

Wilson, James Q. 1961. “The economy of patronage.” The Journal of Political Economy pp. 369_ 380.

$\mathrm{Xu}$, Guo. Forthcoming. "The Costs of Patronage: Evidence from the British Empire.” American Economic Review.

Youde, Jeremy. 2005. "Economics and government popularity in Ghana." Electoral Studies 24(1):1-16. 
Biographical Statement: Sarah Brierley is an Assistant Professor in Political Science at Washington University in St. Louis, St. Louis, MO 63130. 